\title{
Iron and Manganese Retention of Juvenile Zebrafish (Danio rerio) Exposed to Contaminated Dietary Zooplankton (Daphnia pulex)—a Model Experiment
}

\author{
Petra Herman ${ }^{1}$ - Milán Fehér ${ }^{2}$ Áron Molnár ${ }^{2}$ - Sándor Harangi ${ }^{1} \cdot$ Zsófi Sajtos $^{1}$ • László Stündl ${ }^{2}$ | István Fábián ${ }^{1}$. \\ Edina Baranyai ${ }^{1}$ (D)
}

Received: 15 January 2020 / Accepted: 10 May 2020 / Published online: 23 May 2020

(C) The Author(s) 2020

\begin{abstract}
In present study the effect of iron (Fe) and manganese (Mn) contamination was assessed by modeling a freshwater food web of water, zooplankton (Daphnia pulex), and zebrafish (Danio rerio) under laboratory conditions. Metals were added to the rearing media of $D$. pulex, and enriched zooplankton was fed to zebrafish in a feeding trial. The elemental analysis of rearing water, zooplankton, and fish revealed significant difference in the treatments compared to the control. In D. pulex the Mn level increased almost in parallel with the dose of supplementation, as well as the Fe level differed statistically. A negative influence of the supplementation on the fish growth was observed: specific growth rate (SGR\%) and weight gain (WG) decreased in Fe and Mn containing treatments. The redundancy analysis (RDA) of concentration data showed strong correlation between the rearing water and $D$. pulex, as well as the prey organism of Fe- and Mn-enriched D. pulex and the predator organism of $D$. rerio. The bioconcentration factors (BCF) calculated for water to zooplankton further proved the relationship between the Fe and Mn dosage applied in the treatments and measured in D. pulex. Trophic transfer factor (TTF) results also indicate that significant retention of the metals occurred in $D$. rerio individuals, however, in a much lower extent than in the water to zooplankton stage. Our study suggests that Fe and Mn significantly accumulate in the lower part of the trophic chain and retention is effective through the digestive track of zebrafish, yet no biomagnification occurs.
\end{abstract}

Keywords Trophic transfer $\cdot$ Iron $\cdot$ Manganese $\cdot$ Elemental analysis $\cdot$ Daphnia pulex $\cdot$ Danio rerio

\section{Introduction}

Aquatic ecosystems are considered to be the most sensitive environmental media. Emitted pollutants tend to enter first to surface waters, and through the aquatic food chain almost all living organisms can be affected. Metal pollution of surface waters is an ever increasing environmental issue of the last few decades. Pollutants are released into the aquatic ecosystems via anthropogenic activities (industrial and agricultural production, traffic, untreated wastewater effluent etc.); however, the natural geological background can also result in a higher

Edina Baranyai

baranyai.edina@science.unideb.hu

1 Department of Inorganic and Analytical Chemistry, Atomic Spectroscopy Partner Laboratory, University of Debrecen, Debrecen H-4010, Hungary

2 Faculty of the Agricultural and Food Sciences and Environmental Management, University of Debrecen, Debrecen H-4032, Hungary concentration of elemental impurities in the water body [1-3]. Metals accessing to water are usually the lack of biodegradability compared to some organic materials that can be metabolized into less harmful substances [2]. Beside the direct adverse effect of the inorganic contamination on the aquatic plants and organisms resulting in abnormalities, metals can be accumulated in the cells and organs of living individuals [4-6]. Since the trophic levels setting up the aquatic ecosystem are strictly built on each other, more advanced and more complex organisms consuming species from the lower aquatic taxonomy class can create much higher concentrations in their tissue trough bioaccumulation than it was in the initial environmental media [7]. Bioconcentration thus affects nearly all the living organisms in the aquatic ecosystem as well as the human food chain [4, 5], which keeps the subject highly significant [3].

There are several factors on which the tendency and level of bioaccumulation depend: from the distribution of the contaminants through the physical and chemical circumstances (such as salinity, redox conditions, total suspended solid concentration) to the biology of the affected living organisms 
(feeding strategy, age, assimilation efficiency, etc.) [8, 9]. Zhou et al. in their review considering the assessment of metal pollution of aquatic ecosystems concluded that in order to gain a deeper understanding of the pollution routes in aquatic media, further research of bioavailability is necessary [10]. The condition of water ecosystems can be monitored by the continuous analysis of physical and chemical variables; however, significant additional information can be gained by modeling water-related pollution and investigating the effects on different trophic levels by indicator organisms. Biomonitoring plays an important role in this approach offering bioaccumulation level and toxicological effects to support the comprehensive assessment [11]. Toxicity tests are carried out to investigate the effects of various chemicals and contaminants on living organisms, comparing the sensitivity of the different species [12-14]. They are most commonly applied to examine the effect of the polluted media on the vitality, agility, and survival of the indicator organisms [15]. However, by bioindicators, it is also possible to investigate the accumulation of certain pollutants along the food chain, thus gain more detailed information regarding water quality [16-18]. In order to examine the complex effect of more than one contaminant and to evaluate the health condition of the entire aquatic ecosystem, it is important to consider the enrichment along the trophic chain and to examine the biomagnification in the food webs as well. Relationships within the life community can be modeled by multispecies toxicity tests involving more taxa, which are built on each other in the trophic system [19-22].

Both in active and passive aquatic toxicity studies bacteria, algae, zooplankton, and fish species are most commonly examined [23]. These organisms represent different trophic levels in the food chain and-depending on their sensitivity - can provide information about the extent of the pollution in surface waters. At the level of zooplankton organisms, Daphnia pulex is one of the most common bioindicator species of freshwaters due to the many characteristics facilitating its application in biochemical and toxicological studies as well as its relatively simple and cheap raising under laboratory conditions [14, 15, 24]. Daphnia species are considered to be excellent indicators of the surrounding water, and being at the base of the food chain, it is serving as resource for consumers on higher trophic levels, including fish. Zebrafish (Danio rerio) is on the next level in the trophic system and also a very commonly used indicator organism $[25,26]$. Due to its small size, rapid growth, ease of access, and other favorable biological features, individuals are often used not only in toxicity tests but also in biomedical trials. Fernández et al. mentioned in their very recent article that a steady increase can be observed in the past 15 years of publications containing "zebrafish" and "toxic" in the title, reaching an equal to that of the mouse [27].

It is important to take into account the possible routes of exposition when investigating the toxic effect of a chemical.
Depending on the form of the metal compound, uptake paths are through the permeable epidermis or via food ingestion. Since the entire body surface of the aquatic organism gets in connection with the contaminants the adverse effects on the outer epidermis, the digestive tract and the respiratory system may add [28].

According to Koivisto [29] the development of complex test systems corresponding to real nature is needed to better assess and monitor the aquatic environment, while Zhou et al. suggested the establishment of a precaution system for metal pollution including biomonitoring network. In the scope of these approaches the deeper understanding of the metal retention through the food chain is important and can be supported by model experiments under laboratory conditions [22, 30, 31]. Field studies alone are not enough to distinguish between dietary and water-based metal retention [32].

Several studies can be found in the scientific literature investigating the toxic metal retention along the aquatic food web; however, most of them are field studies of freshwater ecosystems [33-37] and even more of them describe results for marine environment [38-40]. Considering the analyzed element, less data are available about Fe and Mn compared to toxic metals such as $\mathrm{Pb}, \mathrm{Cd}$, As, or $\mathrm{Hg}[32,41-44]$. Accordingly, toxic metal concentrations are more strictly regulated. WHO standards for drinking water (2011) has no strict guideline for either Fe or Mn [45] (previous guidelines were discontinued in the latest editions), while USEPA (2012, EPA 822-S-12-001) states maximum levels of $50 \mu \mathrm{g} \mathrm{L}^{-1}$ and $300 \mu \mathrm{g} \mathrm{L}^{-1}$, respectively. EC (1998/83/E) directive is the same for Fe and $200 \mu \mathrm{g} \mathrm{L}^{-1}$ for Mn. Regarding the surface waters and the level of protection necessary for aquatic life, water quality standards give no acute criteria for Fe but contain chronic criteria of $1.000 \mu \mathrm{g} \mathrm{L}^{-1}$. Considering Mn, neither acute nor chronic criteria are stated.

Thus, the aim of the current study is to investigate the trophic transfer and biomagnification of $\mathrm{Fe}$ and $\mathrm{Mn}$ along the aquatic food chain by exposing the metals to juvenile zebrafish via dietary Daphnia pulex. Both metals are important micronutrients and essential for aquatic organisms until reaching a certain concentration limit. The Fe level was reported to show a continuously increasing pattern in Swedish and Finnish surface waters over the last 10 years [46], as well as $\mathrm{Mn}$ is considered to be an emerging contaminant in the aquatic environment [47]. The $\mathrm{Fe}$ and $\mathrm{Mn}$ level of the Hungarian oxbows in the Upper-Tisza region is recently reported to be high as a result of our previous assessment [48] since when we started to conduct model experiments involving these elements. Based on the pollution index of sediment samples, the studied oxbows were characterized by moderate levels of contamination for $\mathrm{Fe}$ and $\mathrm{Mn}$, since the mean geochemical concentration in the upper level $(0-10 \mathrm{~cm})$ of floodplain sediments is exceeded for both elements $\left(35.000 \mathrm{mg} \mathrm{kg}^{-1}\right.$ for $\mathrm{Fe}_{2} \mathrm{O}_{3}$ and $1000 \mathrm{mg} \mathrm{kg}^{-1}$ for $\mathrm{MnO}$ ) [49] [50]. In our first study the $\mathrm{Fe}$ and 
Mn retention was investigated via the rearing water media [28], while in this paper the results of accumulation tendency through food ingestion is described. The elemental concentration of the indicator organisms was determined by microwave plasma atomic emission spectrometry (MP-AES), which is a new and cost-effective technique that can be adapted in the routine analysis of metal pollution.

\section{Materials and Methods}

\section{Animals}

Animal handling and experimental procedures followed the Directive 2010/63/EU of the European Parliament and of the council on the protection of animals used for scientific purposes (2010/63/EU, Official Journal of the European Union. L 276/33. 20.10.2010.)

Water conditions were the same for both the maintenance and treatment and checked regularly. Parameters among the aquaria were not significantly different $(p>0.05)$ and did not affect the treatments. Dissolved oxygen (DO), temperature, and $\mathrm{pH}$ were tested daily by HACH LANGE HQ30D. The level of ammonia, nitrite, and nitrate were measured weekly by spectrophotometry (HACH LANGE DR3900) according to the related USEPA methods $\left(\mathrm{NH}_{4}-\mathrm{N}\right.$ : USEPA NESSLER METHOD, $\mathrm{NO}_{2}$-N: USEPA DIAZOTIZATION METHOD, $\mathrm{NO}_{3}-\mathrm{N}$ : CADMIUM REDUCTION METHOD).

During the experimental period, the following average water quality parameters were determined:

DO : $7.55 \pm 0.34 \mathrm{mg} \mathrm{L}^{-1}$

Water temperature : $22.65 \pm 0.91{ }^{\circ} \mathrm{C}$

$\mathrm{pH}: 8.61 \pm 0.09$

$\mathrm{NH}_{3}{ }^{+}: 0.18 \pm 0.07 \mathrm{mg} \mathrm{L}^{-1}$

$\mathrm{NO}_{2}^{-}: 0.07 \pm 0.11 \mathrm{mg} \mathrm{L}^{-1}$

$\mathrm{NO}_{3}^{-}: 12.6 \pm 6.1 \mathrm{mg} \mathrm{L}^{-1}$

\section{Enrichment of Daphnia pulex with Fe and Mn}

Daphnia pulex individuals were originally collected from a pond then reared isolated and enriched under laboratory conditions in a model system, which ensured optimal environmental conditions for the culture of the zooplankton organisms. The consisting 4-L volume plastic tanks were filled up with continuously aerated tap water, which temperature was kept at $22{ }^{\circ} \mathrm{C}$ and a $16-8 \mathrm{~h}$ (light-dark) of illumination was provided. A day prior to dietary serving the zooplankton, $0.6 \mathrm{~g}$ wet mass of Daphnia was measured into each of the fifteen plastic containers and enriched for $24 \mathrm{~h}$ according to the following treatments:

1. Fe: $5.70 \mathrm{mg} \mathrm{L}^{-1}+\mathrm{Mn}: 2.90 \mathrm{mg} \mathrm{L}^{-1}$

2. Fe: $5.70 \mathrm{mg} \mathrm{L}^{-1}+\mathrm{Mn}: 6.25 \mathrm{mg} \mathrm{L}^{-1}$

3. Fe: $15.0 \mathrm{mg} \mathrm{L}^{-1}+\mathrm{Mn}: 2.90 \mathrm{mg} \mathrm{L}^{-1}$

4. Fe: $15.0 \mathrm{mg} \mathrm{L}^{-1}+\mathrm{Mn}: 6.25 \mathrm{mg} \mathrm{L}^{-1}$

control, no supplementation

Concentrations were adjusted considering our preliminary study where the retention was investigated via rearing water [28]. In this work ten times the previously applied sublethal level of $\mathrm{Fe}$ and $\mathrm{Mn}$ was adjusted to investigate the potential accumulation effect of a toxic concentration range via the chosen aquatic food chain.

The solutions of solid $\mathrm{FeCl}_{3}$ and $\mathrm{MnCl}_{2}$ (analytical purity, SPEKTRUM 3D) were used to adjust the aforementioned concentrations in the model media. Control treatment contained only tap water with the elemental content of the following: $\mathrm{Cu}$ : $7.0 \mu \mathrm{g} \mathrm{L}^{-1}$, Fe: $5.0 \mu \mathrm{g} \mathrm{L}^{-1}, \mathrm{~K}: 2.70 \mathrm{mg} \mathrm{L}^{-1}$, $\mathrm{Mg}: 16.1 \mathrm{mg} \mathrm{L}^{-1}$, Mn: $2.0 \mu \mathrm{g} \mathrm{L}^{-1}$, Na: $31.6 \mathrm{mg} \mathrm{L}^{-1}$, Sr: $0.40 \mathrm{mg} \mathrm{L}^{-1}$, and $\mathrm{Zn}: 41 \mu \mathrm{g} \mathrm{L}^{-1}$, according to ICP-OES analysis. Each treatment was set in triplicate $(n=3)$, and the plastic containers were arranged in a completely randomized design. After the enrichment period, the harvested $D$. pulex organisms were filtered by plankton net of $150-\mu \mathrm{m}$ mesh size and rinsed with ultrapure water (Millipore MilliQ) in three times to evade contamination of the rearing media. Daphnia pulex was fed ad libitum to the zebrafish juveniles.

\section{Enrichment of Danio rerio with Fe- and Mn- Contaminated Daphnia}

Zebrafish juveniles of $60 \mathrm{dph}$ were purchased from a local fish market, and a $48 \mathrm{~h}$ of acclimatization period was applied at $25^{\circ} \mathrm{C}$ prior to the feeding trial. The five treatments in triplicate were arranged in rectangular glass aquaria of $40 \mathrm{~L}$ in a completely randomized design with 10 zebrafish juveniles (5-5 male and female) in each. The initial individual wet body weight was $0.260 \pm 0.035 \mathrm{~g}$, and size homogeneity was tested by ANOVA where no significant difference $(p>0.05)$ occurred among the treatments. Aquaria were filled up with aerated tap water; thus, the oxygen concentration was maintained at $100 \%$ during the 14 days of feeding trial. A $16-8 \mathrm{~h}$ (light-dark) of illumination was provided. Each aquarium was filtered individually, and the flowing as well as aeration of water was provided by piped filters.

The accumulation process of $D$. pulex was replicated daily; thus, zebrafish juveniles were fed freshly enriched zooplankton the same time every morning during the trial without additional supplementation. The amount of zooplankton introduced into the tanks was adjusted to obtain complete 
consumption. A $50 \%$ of water exchange took place daily as well as aquaria were checked for dead individuals.

After the 14 days of enrichment period $D$. rerio individuals were collected by fish net and were rinsed with ultrapure water to reduce the positive error in the analytical results. The individual wet body weight was measured, and samples were kept frozen prior to the sample preparation. The sacrificed procedure was by physical methods suggested in the AVMA Guidelines on Euthanasia for fish reported by the American Veterinary Medical Association [51].

\section{Sample Preparation and Elemental Analysis}

Samples were dried at $105^{\circ} \mathrm{C}$ for $24 \mathrm{~h}$ in a drying cabinet until constant weight, and the dry body weight of the samples was measured on analytical balance (Precisa 360 ES). They were digested on an electric hot plate with $6.0 \mathrm{ml} 65 \%(\mathrm{~m} / \mathrm{m})$ nitric acid (reagent grade, Merck) and $2.0 \mathrm{ml} 30 \%(\mathrm{~m} / \mathrm{m})$ hydrogenperoxide (reagent grade, Merck) at $80{ }^{\circ} \mathrm{C}$ for $4 \mathrm{~h}$. After digestion, samples were diluted with $1 \%(\mathrm{v} / \mathrm{v})$ nitric acid (reagent grade, Merck and Milli-Q water) to a final volume of $12 \mathrm{ml}$ in volume-calibrated test tubes.

Water samples from aquaria were collected every second day to check the concentration of $\mathrm{Fe}$ and $\mathrm{Mn}$ : centrifuge tubes of $10 \mathrm{ml}(\mathrm{PP})$ with screw caps were used for sampling and $1 \mathrm{ml}$ of cc. $\mathrm{HNO}_{3}$ was added to preserve until elemental analysis.

Elemental concentration was determined by microwave plasma atomic emission spectrometer (Agilent MP-AES 4200). Auto sampler (Agilent SPS4), Meinhard® type nebulizer and double-pass spray chamber were used as well as a five-point calibration procedure was applied (ICP VI, Merc). Certified reference material was used (ERM-BB422, fish muscle) to verify that the measured elemental concentrations are equal with the elemental levels of the examined organisms. The recoveries were within $10 \%$ of the certified values for the metals. The wavelengths and measuring parameters were chosen based on the suggestion of the instrument's software (MP Expert).

\section{Data Evaluation}

Weight gain (WG) percentage was calculated from the measured initial and final wet weight $\left(W_{i}\right.$ and $W_{f}$, respectively) data of D. rerio individuals:

$\mathrm{WG}(\%)=\left(\mathrm{W}_{\mathrm{f}}-\mathrm{W}_{\mathrm{i}}\right) / \mathrm{W}_{\mathrm{i}} \cdot 100$

Specific growth rate (SGR) was applied to describe the growing performance of $D$. rerio according to the following formula:

$\operatorname{SGR}(\% /$ day $)=\left(\ln \mathrm{W}_{\mathrm{f}}-\ln \mathrm{W}_{\mathrm{i}}\right) / \mathrm{t} \cdot 100$,

where $W_{f}$ is the final wet body weight and $W_{i}$ is the initial wet body weight of the zebrafish individuals [52].
The bioconcentration factor (BCF) for D. pulex was calculated by dividing the $\mathrm{Fe}$ and $\mathrm{Mn}$ concentration measured in the zooplankton $\left(C_{\text {tissue }}, \mathrm{mg} \mathrm{kg}^{-1}\right.$ dry weight $)$ by the same concentration values of the rearing water media $\left(C_{\text {water }}, \mathrm{mg} \mathrm{L}^{-1}\right)$ [28]:

$\mathrm{BCF}=C_{\text {tissue }} / C_{\text {water }}$

Trophic transfer factor (TTF) was calculated as the ratio of the tissue concentration of $\mathrm{Fe}$ and $\mathrm{Mn}$ measured in D. rerio $\left(C_{\text {predator }}\right)$ and the tissue concentration of the two elements measured in D. pulex $\left(C_{\text {prey }}\right)$ both given in $\mathrm{m} \mathrm{kg}^{-1}$ dry weight [53]:

$\mathrm{TTF}=C_{\text {predator }} / C_{\text {prey }}$

The statistical evaluation of experimental data was carried out in SpSS/PC+ software package. ANOVA was applied to study the WG, SGR, BCF, TTF, and elemental concentration results of the applied treatments. The homogeneity of variance was checked by Levene test, and significant differences were investigated by Tukey multi-comparison test where difference was considered to be statistically proven when $p<0.05$. Redundancy analysis (RDA) was performed in Canoco for Windows 4.5 to study the interaction between the studied species and their environmental background: $D$. pulex/water and D. rerio/D. pulex, respectively.

\section{Results}

\section{Survival and Growth Performance of Danio rerio Fed with Fe- and Mn-Contaminated Daphnia}

The survival of zebrafish juveniles was $100 \%$ in all treatments; thus, the applied concentrations of $\mathrm{Fe}$ and $\mathrm{Mn}$ did not cause the mortality of fish individuals during the experimental period. The average final wet weight of fish increased in all treatments compared to the initial values (Fig. 1) indicating that the metal supplementation did not result in growth abnormality; however, reduced growth performance was observed. The highest percentage values of SGR and WG were achieved by the control group (Table 1), which suggests that feeding Fe- and Mn-enriched D. pulex might had a negative influence on fish growth.

\section{Elemental Concentration of Fe- and Mn-Enriched Daphnia pulex and Danio rerio}

The Fe and Mn concentration of $D$. pulex calculated to dry weight is indicated in Fig. 2 a and b, respectively.

Both the Fe and Mn level of the zooplankton samples in all the applied treatments increased significantly compared to the control group $(p<0.001, F=4.319$ and $F=12.236$, 
Fig. 1 The average initial and final wet weight of zebrafish individuals in the different treatments (mean $\pm \mathrm{SE}, n=3$ ) Control: fed by nonsupplemented Daphnia, 1: fed by Daphnia supplemented with $5.70 \mathrm{mg} \mathrm{L}^{-1} \mathrm{Fe}$ and $2.90 \mathrm{mg} \mathrm{L}^{-1}$ Mn, 2: fed by Daphnia supplemented with $5.70 \mathrm{mg} \mathrm{L}^{-1}$ Fe and $6.25 \mathrm{mg} \mathrm{L}^{-1} \mathrm{Mn}, 3$ : fed by Daphnia supplemented with $15.0 \mathrm{mg} \mathrm{L}^{-1} \mathrm{Fe}$ and $2.90 \mathrm{mg} \mathrm{L}^{-1}$ Mn, 4: fed by Daphnia supplemented with $15.0 \mathrm{mg} \mathrm{L}^{-1}$ $\mathrm{Fe}$ and $6.25 \mathrm{mg} \mathrm{L}^{-1} \mathrm{Mn}$

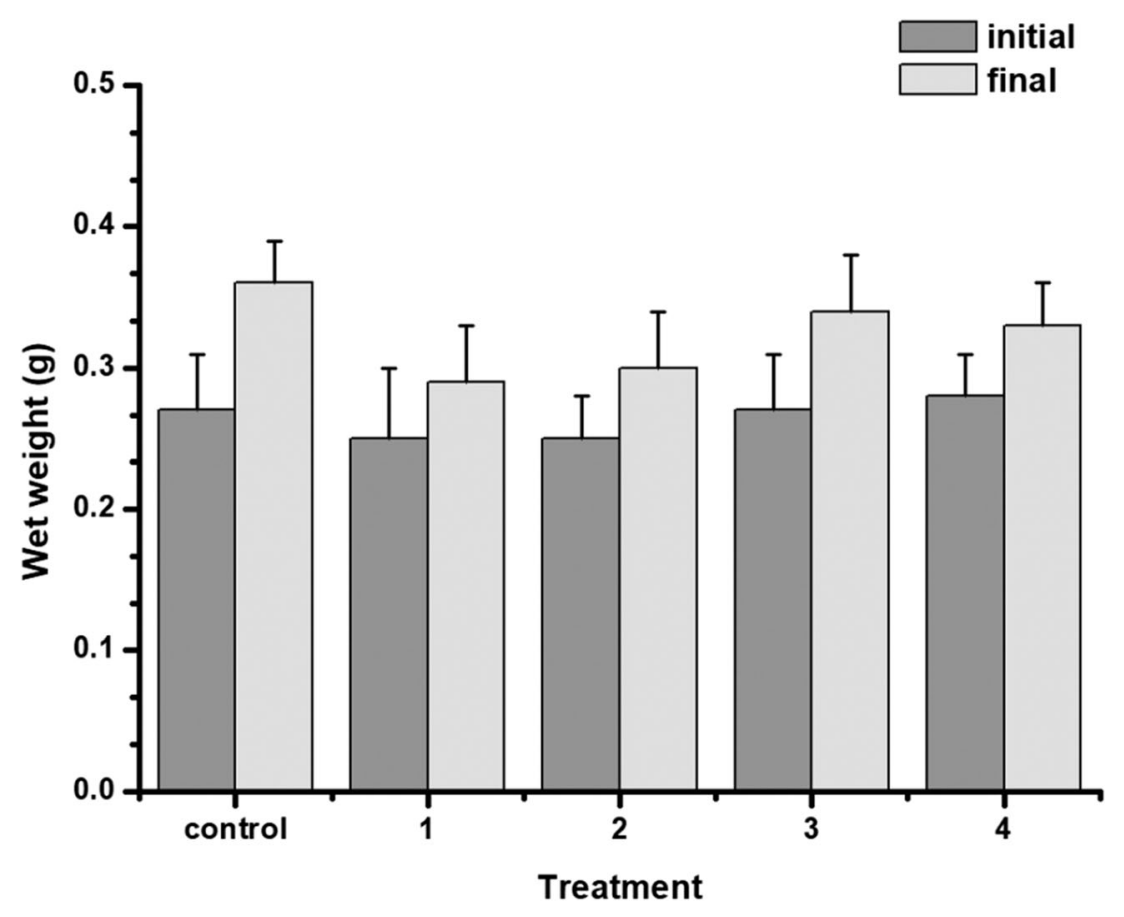

respectively). Considering the Mn content, the treatments containing the same Mn supplementation $\left(2.90 \mathrm{mg} \mathrm{L}^{-1}\right.$ in numbers 1 and 3 as well as $6.25 \mathrm{mg} \mathrm{L}^{-1}$ in numbers 2 and 4) did not differ statistically from each other $(p>0.05)$ (Fig. 2b). Similar results for Fe were gained (Fig. 2a): its concentration in treatment numbers 1 and 2 (both containing $5.70 \mathrm{mg} \mathrm{L}^{-1}$ $\mathrm{Fe})$ is statistically comparable $(p>0.05)$ as well as in treatment numbers 3 and 4 (both containing $15.0 \mathrm{mg} \mathrm{L}^{-1}$ ) $(p>0.05)$. However, in contrast to $\mathrm{Mn}$, the Fe level differed less between the treatments supplemented with the lower (5.70 $\left.\mathrm{mg} \mathrm{L}^{-1}\right)$ and the higher $\left(15.0 \mathrm{mg} \mathrm{L}^{-1}\right)$ dosage $(p<0.05$, respectively).

The average $\mathrm{Fe}$ and $\mathrm{Mn}$ concentration of zebrafish juveniles per treatments are indicated in Fig. $2 \mathrm{c}$ and d, respectively. The Fe content of all groups increased compared to the

Table 1 Specific growth rate and weight gain percentage of Danio rerio in different treatments (mean $\pm \mathrm{SE}, n=3$ ). Control: fed by nonsupplemented Daphnia, 1: fed by Daphnia supplemented with $5.70 \mathrm{mg} \mathrm{L}^{-1} \mathrm{Fe}$ and $2.90 \mathrm{mg} \mathrm{L}^{-1} \mathrm{Mn}$, 2: fed by Daphnia supplemented with $5.70 \mathrm{mg} \mathrm{L}^{-1} \mathrm{Fe}$ and $6.25 \mathrm{mg} \mathrm{L}^{-1} \mathrm{Mn}$, 3: fed by Daphnia supplemented with $15.0 \mathrm{mg} \mathrm{L}^{-1} \mathrm{Fe}$ and $2.90 \mathrm{mg} \mathrm{L}^{-1} \mathrm{Mn}$, 4: fed by Daphnia supplemented with $15.0 \mathrm{mg} \mathrm{L}^{-1} \mathrm{Fe}$ and $6.25 \mathrm{mg} \mathrm{L}^{-1} \mathrm{Mn}$. Letters in lowercase indicate significant differences $(p<0.05)$

\begin{tabular}{lll}
\hline Treatments & SGR (\%/day) \pm SE & WG $(\%) \pm$ SE \\
\hline Control & $2.20 \pm 0.63 \mathrm{a}$ & $37.0 \pm 11.7 \mathrm{a}$ \\
1 & $1.15 \pm 0.24 \mathrm{~b}$ & $17.5 \pm 3.93 \mathrm{~b}$ \\
2 & $1.42 \pm 0.47 \mathrm{c}$ & $22.6 \pm 7.96 \mathrm{bc}$ \\
3 & $1.68 \pm 0.52 \mathrm{c}$ & $27.3 \pm 9.01 \mathrm{c}$ \\
4 & $1.15 \pm 0.26 \mathrm{~b}$ & $17.6 \pm 4.25 \mathrm{~b}$ \\
\hline
\end{tabular}

control $(F=4.013, p<0.05)$; however, the two different applied Fe concentrations did not affect the Fe level of the zebrafish individuals - no statistical difference was found either between treatments 1 and $2\left(5.70 \mathrm{mg} \mathrm{L}^{-1}\right)(p>0.05)$ or between treatments 3 and $4\left(15.0 \mathrm{mg} \mathrm{L}^{-1}\right)(p>0.05)$. The Mn concentration of the fish also increased significantly compared to the non-supplemented control group $(F=16.132$, $p<0.001)$.

The elemental composition of $D$. rerio individuals can be seen in Table 2. No significant difference occurred in the composition of the samples regarding the trace element pattern either compared to the control $(p>0.05$, respectively, and Ca: $F=1.668 ; \mathrm{Cu}: F=2.286 ; \mathrm{Mg}: F=1.271$; Na: $F=0.895$; $\mathrm{Zn}: F=0.887$ ) or between the treatments, except for $\mathrm{Co}$ $(p<0.01, F=37.326)$.

\section{Interaction Between the Fe and Mn Levels of Water, Daphnia pulex, and Danio rerio}

Redundancy analysis was applied to assess the interaction between the level of Fe and $\mathrm{Mn}$ in the treatments and in the studied aquatic species, which is a commonly applied statistical technique to explain and model different cause-effect relationships [54]. The RDA biplot regarding the Fe and $\mathrm{Mn}$ concentration of the rearing water and D. pulex is indicated in Fig. 3. In the first component (RDA1) the correlation between Fe and Mn concentration of the rearing media and the concentration of the same elements in D. pulex was 0.884 , while in the second component (RDA2) the correlation was 0.858 . The cumulative percentage variance of elemental concentration of the zooplankton was 77.2 (RDA1) and 78.1 
a

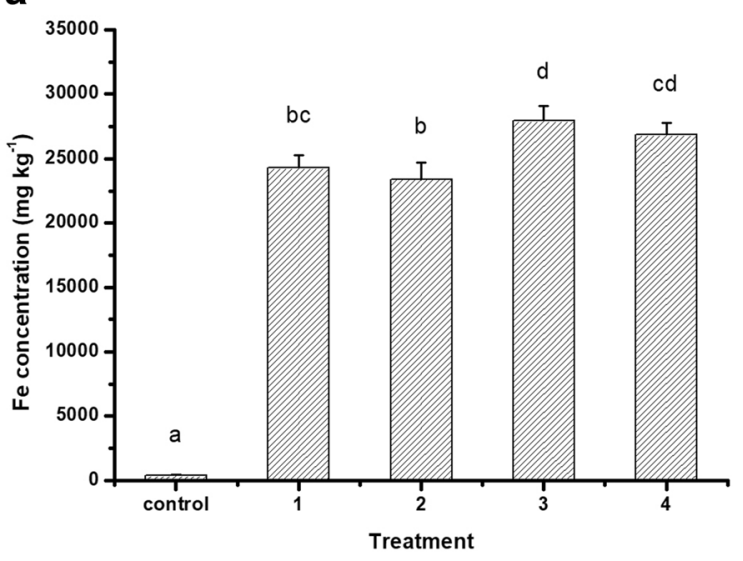

C

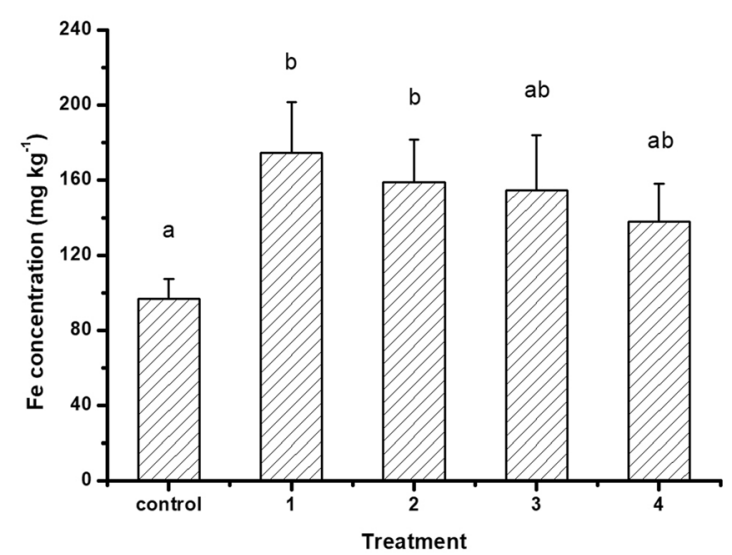

Fig. 2 The Fe (a) and Mn (b) concentration of supplemented Daphnia pulex and zebrafish (c and d, respectively) (mean \pm SE dry weight, $n=3$ ) Control: non-supplemented, 1: supplemented with $5.70 \mathrm{mg} \mathrm{L}^{-1} \mathrm{Fe}$ and $2.90 \mathrm{mg} \mathrm{L}^{-1} \mathrm{Mn}$, 2: supplemented with $5.70 \mathrm{mg} \mathrm{L}^{-1} \mathrm{Fe}$ and $6.25 \mathrm{mg} \mathrm{L}^{-1}$

(RDA2). The relation regarding the species-environment connection revealed to be 98.9 (RDA1) and 100.0 (RDA2). The biplot shows a relatively strong correlation between the $\mathrm{Fe}$ b

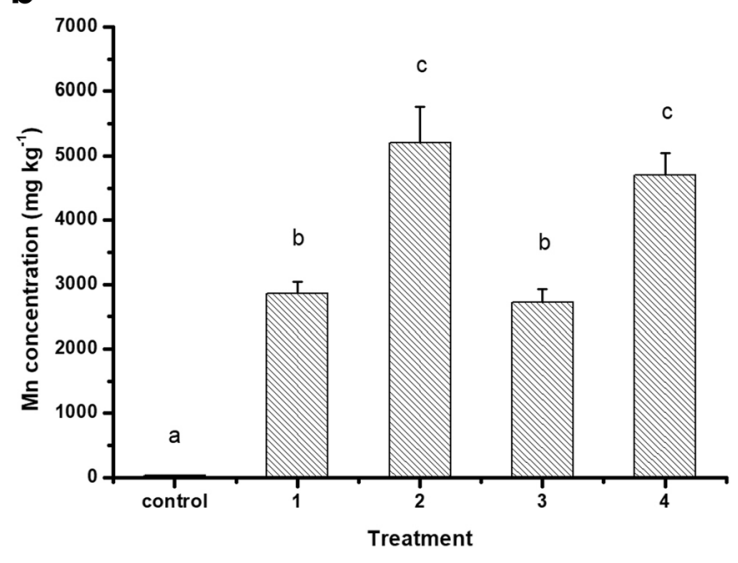

d

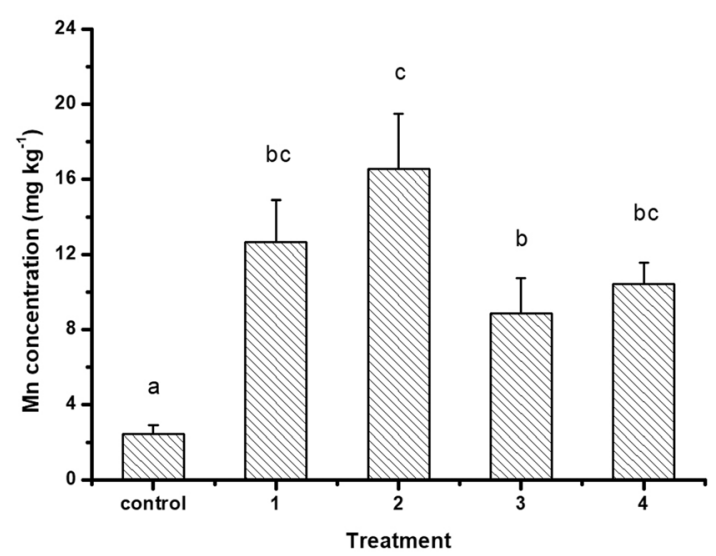

Mn, 3: supplemented with $15.0 \mathrm{mg} \mathrm{L}^{-1} \mathrm{Fe}$ and $2.90 \mathrm{mg} \mathrm{L}^{-1} \mathrm{Mn}, 4$ : supplemented with $15.0 \mathrm{mg} \mathrm{L}^{-1} \mathrm{Fe}$ and $6.25 \mathrm{mg} \mathrm{L}^{-1} \mathrm{Mn}$. Letters above columns indicate significant differences $(p<0.05)$

levels of the Fe- and Mn-contaminated water as well as the reared zooplankton individuals, and a total agreement between the Mn concentrations.
Table 2 Elemental concentration ( $\mathrm{mg} \mathrm{kg}^{-1}$, dry weight) of Danio rerio in different treatments (mean $\pm \mathrm{SE}, n=3$ ). Control: fed by nonsupplemented Daphnia, 1: fed by Daphnia supplemented with $5.70 \mathrm{mg} \mathrm{L}^{-1} \mathrm{Fe}$ and $2.90 \mathrm{mg} \mathrm{L}^{-1} \mathrm{Mn}, 2$ : fed by Daphnia supplemented with $5.70 \mathrm{mg} \mathrm{L}^{-1} \mathrm{Fe}$ and $6.25 \mathrm{mg} \mathrm{L}^{-1} \mathrm{Mn}$, 3: fed by Daphnia supplemented with $15.0 \mathrm{mg} \mathrm{L}^{-1} \mathrm{Fe}$ and $2.90 \mathrm{mg} \mathrm{L}^{-1} \mathrm{Mn}$, 4: fed by Daphnia supplemented with $15.0 \mathrm{mg} \mathrm{L}^{-1} \mathrm{Fe}$ and $6.25 \mathrm{mg} \mathrm{L}^{-1} \mathrm{Mn}$. Letters in lowercase indicate significant differences $(p<0.05)$

\begin{tabular}{|c|c|c|c|c|c|c|c|}
\hline Treatment & & $\mathrm{Ca}\left(\mathrm{mg} \mathrm{kg}^{-1}\right)$ & Co $\left(\mathrm{mg} \mathrm{kg}^{-1}\right)$ & $\mathrm{Cu}\left(\mathrm{mg} \mathrm{kg}^{-1}\right)$ & $\mathrm{Mg}\left(\mathrm{mg} \mathrm{kg}^{-1}\right)$ & $\mathrm{Na}\left(\mathrm{mg} \mathrm{kg}^{-1}\right)$ & $\mathrm{Zn}\left(\mathrm{mg} \mathrm{kg}^{-1}\right)$ \\
\hline \multirow{2}{*}{$\begin{array}{l}\text { Control } \\
N=30\end{array}$} & \multirow{2}{*}{ Mean \pm SE } & 29.346 & $0.346 \mathrm{a}$ & 7.52 & 1046 & 2438 & 228 \\
\hline & & 1864 & 0.0555 & 0.608 & 44.5 & 85.1 & 15.1 \\
\hline \multirow{2}{*}{$\begin{array}{l}1 \\
N=30\end{array}$} & \multirow{2}{*}{ Mean $\pm \mathrm{SE}$} & 30.968 & $0.607 b$ & 8.63 & 1081 & 2449 & 245 \\
\hline & & 2854 & 0.118 & 1.16 & 84.7 & 277 & 24.3 \\
\hline \multirow{2}{*}{$\begin{array}{l}2 \\
N=30\end{array}$} & \multirow{2}{*}{ Mean $\pm \mathrm{SE}$} & 33.789 & $0.924 \mathrm{c}$ & 9.75 & 1168 & 2637 & 255 \\
\hline & & 3754 & 0.101 & 1.32 & 69.3 & 129 & 14.7 \\
\hline \multirow{2}{*}{$\begin{array}{l}3 \\
N=30\end{array}$} & \multirow[t]{2}{*}{ Mean \pm SE } & 32.963 & $1.06 \mathrm{c}$ & 7.99 & 1094 & 2369 & 244 \\
\hline & & 2073 & 0.0623 & 0.715 & 52.8 & 252 & 11.4 \\
\hline \multirow{2}{*}{$\begin{array}{l}4 \\
N=30\end{array}$} & \multirow[t]{2}{*}{ Mean $\pm \mathrm{SE}$} & 33.714 & $1.09 \mathrm{c}$ & 7.97 & 1108 & 2462 & 255 \\
\hline & & 2518 & 0.0842 & 0.716 & 65.8 & 187 & 19.4 \\
\hline
\end{tabular}



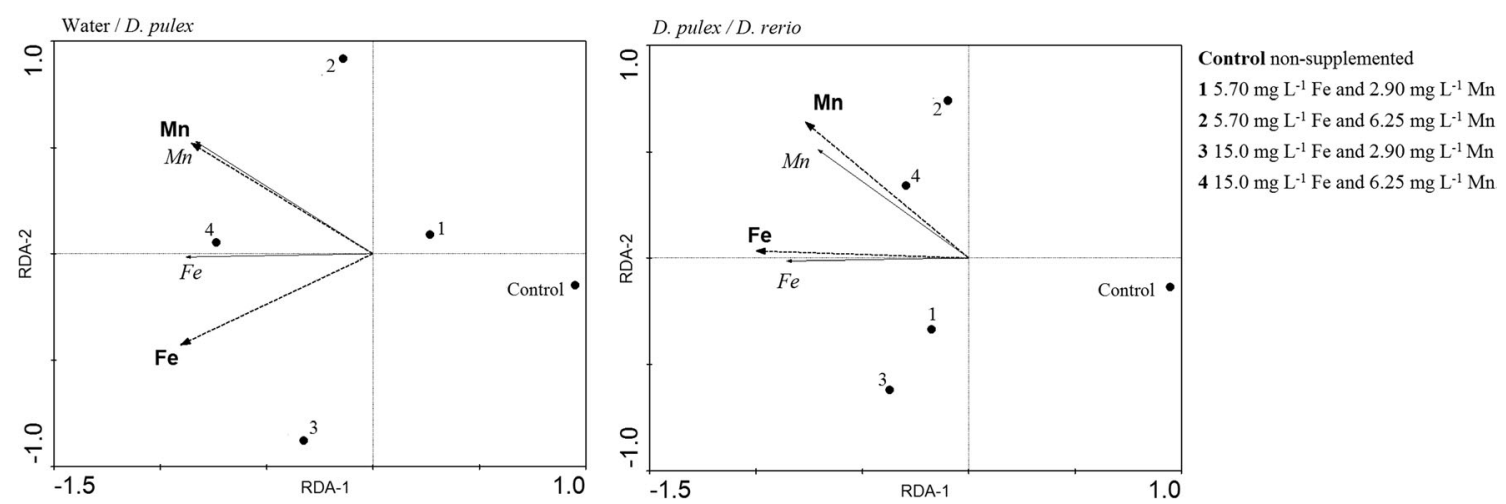

Fig. 3 The RDA biplots of the Fe and Mn level of rearing water and $D$. pulex as well as of $D$. pulex and $D$. rerio (solid arrow: elemental concentration of water $/ D$. pulex, dashed arrow: elemental concentration of $D$. pulex/D. rerio. Filled circles with numbers indicate experimental groups)

Very similar results were obtained for the RDA of the Fe and $\mathrm{Mn}$ content of $D$. pulex reared in contaminated water media and $D$. rerio fed by the enriched zooplankton organism, shown also in Fig. 3. The correlation between $\mathrm{Fe}$ and $\mathrm{Mn}$ concentrations in the relation of $D$. pulex and $D$. rerio in RDA1 was 0.855 , while in RDA2 the correlation was 0.987 . The cumulative percentage variances of $\mathrm{Fe}$ and $\mathrm{Mn}$ level of the zebrafish were 72.4 (RDA1) and 73.3 (RDA2). The species-environment connection was found to be 98.8 (RDA1) and 100.0 (RDA2).

\section{Bioconcentration and Trophic Transfer Factor of Daphnia pulex and Danio rerio}

Bioconcentration factors calculated from water to zooplankton for Fe and $\mathrm{Mn}$ are summarized in Table 3. Statistically significant difference occurred ( $p<0.05$, Fe: $F=21.727$; Mn: $F=3.407$ ) between the treatments containing $5.7 \mathrm{mg} \mathrm{L}^{-1} \mathrm{Fe}$ (treatments 1 and 2) and the treatments containing

Table 3 Bioconcentration factors (mean $\pm \mathrm{SE}$ ) of Fe and $\mathrm{Mn}$ from water to Daphnia pulex. Control: non-supplemented, 1: supplemented with $5.70 \mathrm{mg} \mathrm{L}^{-1} \mathrm{Fe}$ and $2.90 \mathrm{mg} \mathrm{L}^{-1} \mathrm{Mn}, 2$ : supplemented with $5.70 \mathrm{mg} \mathrm{L}^{-1} \mathrm{Fe}$ and $6.25 \mathrm{mg} \mathrm{L}^{-1} \mathrm{Mn}$, 3: supplemented with $15.0 \mathrm{mg} \mathrm{L}^{-1} \mathrm{Fe}$ and $2.90 \mathrm{mg} \mathrm{L}^{-1} \mathrm{Mn}$, 4: supplemented with $15.0 \mathrm{mg} \mathrm{L}^{-1} \mathrm{Fe}$ and $6.25 \mathrm{mg} \mathrm{L}^{-1} \mathrm{Mn}$. Letters in lowercase indicate significant differences $(p<0.05)$

\begin{tabular}{llr}
\hline Elements & Treatments & \multicolumn{1}{l}{ BCF } \\
\hline Fe & 1 & $4591 \pm 105 \mathrm{a}$ \\
& 2 & $4371 \pm 169 \mathrm{a}$ \\
& 3 & $1902 \pm 31.1 \mathrm{~b}$ \\
& 4 & $1864 \pm 33.0 \mathrm{~b}$ \\
$\mathrm{Mn}$ & 1 & $1044 \pm 54.3 \mathrm{a}$ \\
& 2 & $925 \pm 96.3 \mathrm{~b}$ \\
& 3 & $1006 \pm 35.9 \mathrm{a}$ \\
& 4 & $799 \pm 17.3 \mathrm{~b}$ \\
\hline
\end{tabular}

$15.0 \mathrm{mg} \mathrm{L}^{-1}$ (treatments 3 and 4). Groups supplemented with the same dosage of Fe did not differ from each other significantly $(p>0.05)$. Higher supplemented level resulted in lower $\mathrm{BCF}$ values. The same is true for $\mathrm{Mn}$ : the higher dose of enrichment provided lower BCF proving the relation between the measured concentration of the two elements applied in the treatments and in the zooplankton organisms. The BCF data for $\mathrm{Fe}$ in the treatments 1 and 2 are nearly four times to that of the Mn. The TTF values are summarized in Table 4 for $D$. rerio exposed to dietary $\mathrm{Fe}$ and $\mathrm{Mn}$ via $D$. pulex, showing less difference yet still statistically proven $(p<0.05, \mathrm{Fe}=F=$ 2.597; Mn: $F=5.092$ ).

\section{Discussion}

The accumulation tendency of different pollutants carries essential information regarding the water quality, the well-being

Table 4 Trophic transfer factors (mean \pm SE) for Fe and $\mathrm{Mn}$ from Daphnia pulex to Danio rerio. Control: fed by non-supplemented Daphnia, 1: fed by Daphnia supplemented with $5.70 \mathrm{mg} \mathrm{L}^{-1} \mathrm{Fe}$ and $2.90 \mathrm{mg} \mathrm{L}^{-1} \mathrm{Mn}, 2$ : fed by Daphnia supplemented with $5.70 \mathrm{mg} \mathrm{L}^{-1}$ $\mathrm{Fe}$ and $6.25 \mathrm{mg} \mathrm{L}^{-1} \mathrm{Mn}$, 3: fed by Daphnia supplemented with $15.0 \mathrm{mg} \mathrm{L}^{-1} \mathrm{Fe}$ and $2.90 \mathrm{mg} \mathrm{L}^{-1} \mathrm{Mn}$, 4: fed by Daphnia supplemented with $15.0 \mathrm{mg} \mathrm{L}^{-1} \mathrm{Fe}$ and $6.25 \mathrm{mg} \mathrm{L}^{-1} \mathrm{Mn}$. Letters in lowercase indicate significant differences $(p<0.05)$

\begin{tabular}{lll}
\hline Elements & Treatments & TTF $\times 10^{-3}$ \\
\hline $\mathrm{Fe}$ & 1 & $7.19 \pm 0.410 \mathrm{a}$ \\
& 2 & $6.74 \pm 0.627 \mathrm{a}$ \\
& 3 & $5.51 \pm 0.616 \mathrm{~b}$ \\
$\mathrm{Mn}$ & 4 & $5.15 \pm 0.720 \mathrm{~b}$ \\
& 1 & $4.45 \pm 0.208 \mathrm{a}$ \\
& 2 & $3.26 \pm 0.555 \mathrm{~b}$ \\
& 3 & $3.26 \pm 0.410 \mathrm{~b}$ \\
& 4 & $2.23 \pm 0.351 \mathrm{c}$ \\
\hline
\end{tabular}


of aquatic ecosystems, and is directly related to human health. The appearance of iron and manganese in water ecosystems can originate from industrial and agricultural emissions; however, the natural geological background can result in elevated levels.

The growth performance of zebrafish juveniles was found to be slightly affected by the environmentally toxic levels of $\mathrm{Fe}$ and Mn since lower values of SGR and WG were detected compared to the control group. This finding is in contrast with our previous experiment where the sublethal level of Fe and $\mathrm{Mn}$ retention was studied from water via the gills of Common carp (Cyprinus carpio) [28]. In that study ten times lower level of the two elements were applied in a very similar experimental setup; thus, we can conclude that the elevated dose of $\mathrm{Fe}$ and $\mathrm{Mn}$ supplementation in present investigation reached the value where it affects the growth performance. The negative influence of $\mathrm{Mn}$ in fish is mainly due to the increased oxidative stress it provokes [55-58]. Gabriel et al. described the toxicity of $\mathrm{Mn}$ exposed to juvenile Colossoma macropomum by evaluating oxidative stress parameters and found that biomarkers changed significantly in the tissues of the studied fish individuals proving specific toxicity of $\mathrm{Mn}$ to the different organs [58]. In contrast, low level of Mn supplementation in fish diet can have opposite effect by promoting growth and normal skeleton development [20].

The Mn level in the zooplankton organisms increased in parallel with the dose of the applied supplementation. The same phenomenon was observed by Fehér et al. in a 24-h enrichment trial of Artemia nauplii with $\mathrm{MnCl}_{2}$ [52]. The high bioconcentration potential of mainly herbivores Daphnia species is published compared to omnivorous species, such as rotifers, for $\mathrm{Cd}, \mathrm{As}$, and $\mathrm{Pb}$ [33]. However, the two different applied Fe concentrations in treatments did not result in significantly different uptake level of the zebrafish individuals. This finding correlates with the results obtained by Harangi et al., who conduct experiments to study the accumulation of metals in juvenile carp exposed to sublethal levels of $\mathrm{Fe}$ and $\mathrm{Mn}$ [28]. Either the smaller accumulation tendency of Fe can be one of the possible explanations or the higher hydrolyzation potential of $\mathrm{Fe}$ in the model media in which the zooplankton organism was reared. However, compared to the control group, the concentration of both the studied elements increased. This finding proves that nevertheless the main uptake path for dissolved $\mathrm{Fe}$ and $\mathrm{Mn}$ for fish is via the gills; retention is also efficient through the digestive track. Since the level of the other essential elements did not change upon the Fe and Mn treatments, we can further conclude that the applied concentration of $\mathrm{Fe}$ and $\mathrm{Mn}$ did not affect the metabolism process of other metals.

The good correlation indicated in the redundancy analysis proves the direct connection between the Fe and Mn concentration of the zooplankton organisms as well as the zebrafish individuals with the applied treatments, thus the ability of these elements to concentrate in the aquatic food chain. Fehér et al. used RDA to reveal the effect between the elemental content of a saltwater zooplankton (Artemia naupli) species and Barramundi (Lates calcarifer) larvae [52]. In their experimental setup the zooplankton was reared in a $\mathrm{Mn}, \mathrm{Zn}$, and Co supplemented water media and barramundi individuals were fed by the enriched Artemia. Similar to present study, they found correlation between the environmental and species concentration data for $\mathrm{Mn}$.

Bioconcentration of organic and inorganic pollutants in aquatic organisms is a significant parameter to assess the effect of chemicals emitted to the environment. It can be expressed numerically in experiments conducted under laboratory conditions by the bioaccumulation factor, which can be used for regulatory purposes if certain limitations are considered [59]. The BCF of present study proved the relation between the level of $\mathrm{Fe}$ and $\mathrm{Mn}$ in the treatments and in the zooplankton organisms. Manganese is a commonly occurring element in the aquatic environment, in both underground and surface waters. Although it is an essential element, even a short-term waterborne exposure to higher concentration can indicate peroxidative damage in fish tissues [60]. Marins et al. in their fresh study from 2019 found that long-term exposure to $\mathrm{Fe}$ and $\mathrm{Mn}$ in a concentration commonly found in groundwater may cause damage to chromosome levels and changes in locomotor and exploratory behaviors of adult zebrafish [61]. It was further concluded by $\mathrm{Tu} \mathrm{H}$. et al. that developmental exposure to $\mathrm{Mn}$ along with $\mathrm{Cd}$ and $\mathrm{Pb}$ statistically reduced the velocity and distance of the larval swim of zebrafish [62]. Altenhofen et al. studied the effect of $\mathrm{MnCl}_{2}$ exposure on cognition and exploratory behavior in adult and larval zebrafish. Both adults and larvae reacted with decreased distance traveled and absolute body turn angle as well as increased apoptotic markers were found in their nervous system. The research group concluded that the prolonged Mn exposure resulted in locomotor deficits that can damage the dopaminergic system [63].

The BCF results for Fe in the first two treatments of present study are higher than the same data for Mn. In our previous study the Fe and Mn bioconcentration was investigated from water to fish (Common carp) in a model experiment and similar tendency was found [28]. Voigt et al. also reported much higher BCF for Fe compared to Mn in the tissue of Geophagus brasiliensis originating from Alagados Reservoir, Ponta Grossa [64]. Iron can affect both directly and indirectly the living organisms in aquatic ecosystems and, according to the suggestion to Vuori, the ecotoxicological aspects of Fe should be further analyzed with organisms of different levels [65].

Liu et al. in their paper suggested the further investigation of the relative importance between the aqueous and dietary exposure of metals to fish in order to deeper understand the processes of metal transfer into the fish body [30]. In agreement with this conclusion in our last study we investigated the 
effect of waterborne Fe and Mn on the tissue of indicator fish, while in present work the dietary Fe and Mn is tested. Trophic transfer factor can be used for the latter purpose to express the bioconcentration from zooplankton to fish [53]. The results of TTF are more homogenous compared to BCF proving less difference between the applied concentration of dietary Fe and Mn. The values suggest that transfer definitely occurs from zooplankton to fish for the studied metals yet in a lower extent than directly from water to fish, as described in our previous study [28]. According to the results of Zhu et al. $D$. rerio could also accumulate $\mathrm{nTiO}_{2}$ by aqueous exposure with higher bioaccumulation factors compared to the dietary intake.

Biomagnification is not observed in present study along the water to $D$. pulex to $D$. rerio trophic route. This finding meets previously published research data stating that BCF and TTF usually increase along the given aquatic food chain right until the level of fish where it starts to decrease significantly. Pianpian et al. concluded in their meta-analysis that the average $\mathrm{MeHg}$ bioaccumulation from water to either seston or zooplankton was over 6 order of magnitude greater than the biomagnification from zooplankton to preyfish [66]. Mathews et al. studied the retention of $\mathrm{MeHg}, \mathrm{Cd}$, and $\mathrm{Po}$ in an estuarine food chain and found a greater biomagnification at the trophic step of $D$. pulex feeding on phytoplankton [67]. This phenomenon is commonly explained by the higher availability of toxic elements to organisms at lower trophic levels [68]. Our study further confirms Oweson and Hernroth finding that Mn tends to accumulate strongly in aquatic organisms situated lower in the food web [69].

It was also long found that aquatic vertebrates as fish can efficiently excrete ingested heavy metals, especially the noessential and toxic ones [70]. Increased BCF factor for Fe and Mn was observed from water to fish in our previous experiment compared to the current one, where only in the absorption trough the respiratory and dermal surfaces was considered [28]. It further indicates that retention of waterborne $\mathrm{Fe}$ and $\mathrm{Mn}$ is stronger compared to the dietary one; however, the accumulation extent of elements vary among the metals and metal species showing very different behavioral patterns. For example, the main route of $\mathrm{Cd}$ accumulation in marine environment is considered to be the dietary exposure as well as most of the other metals that have been studied in the past decades [71]. For freshwater ecosystems $\mathrm{Cd}$ was found to enrich strongly in the trophic chain, while no enrichment tendency of $\mathrm{Cu}$ was observed in the same survey [72]. The accumulation tendency of Mn was investigated by Niemiec et al. in a field study resulting in much higher BCF values from water to Ciprinus carpio in the analyzed ecosystem than other routes.

It is also proven by several field studies and laboratory experiments that toxic elements are accumulated in certain organs contributing to a small extent to the total weight of the fish body explaining the lower level of retention results. This finding is confirmed for waterborne Fe and $\mathrm{Mn}$ in our last experiment where both were absorbed in the highest level in the liver of Common carp juveniles [28]. Metals stored in the form of granules usually have lower bioavailability to the predator organisms [73].

The so-called grow dilution may also take part in the smaller TTF values from zooplankton to $D$. rerio compared to the $\mathrm{BCF}$ data given for water to D. pulex. This pseudo-elimination process occurs due to the increase of fish tissue during the experimental time and results in a lower determined BCF values even more under laboratory circumstances [59, 74].

\section{Conclusion}

Present work indicates the importance of model experiments to gain more detailed information regarding the accumulation tendency of metals, not limited solely to the non-essential ones. It highlights that laboratory circumstances provide the possibility to investigate only one absorption pathway at a time and to selectively exclude the others. Iron and manganese are essential elements to a certain level above which both have negative influence on aquatic organisms. Our work proves that the main step from the point of bioconcentration occurs in the lower part of the trophic system since higher accumulation tendency was observed in the first stage of the investigated food web. The results demonstrate that concentrations of Fe and $\mathrm{Mn}$ well above the environmentally accepted levels still do not cause mortality neither biomagnification in the studied organisms; however, retention in the growth performance of $D$. rerio was observed. The lack of acute toxicity thus does not translate into no negative effect. It is mentioned in literature that damage to chromosome levels and changes in locomotor and exploratory behavior is resulted in long-term exposures. Further model studies are therefore recommended to investigate the dietary Fe and Mn absorption in the different organs and tissues of fish to supplement research approaches determining the biochemical adverse effects, such as oxidative stress.

Acknowledgments We acknowledge the Agilent Technologies, Inc. and the Novo-Lab Ltd. (Hungary) for providing the MP-AES 4200 and the ICP-OES 5100 instruments for the elemental analysis.

Funding Information Open access funding provided by University of Debrecen (DE). The research was supported by the EU and co-financed by the European Regional Development Fund under the project GINOP2.3.2-15-2016-00008. Petra Herman was supported through the New National Excellence Program of the Ministry of Human Capacities.

\section{Compliance with Ethical Standards}

Conflict of Interest The authors declare that they have no conflict of interest. 
Ethical Approval All experiments and procedures were performed in compliance with relevant laws and institutional guidelines, and the appropriate institutional committee have approved them.

Open Access This article is licensed under a Creative Commons Attribution 4.0 International License, which permits use, sharing, adaptation, distribution and reproduction in any medium or format, as long as you give appropriate credit to the original author(s) and the source, provide a link to the Creative Commons licence, and indicate if changes were made. The images or other third party material in this article are included in the article's Creative Commons licence, unless indicated otherwise in a credit line to the material. If material is not included in the article's Creative Commons licence and your intended use is not permitted by statutory regulation or exceeds the permitted use, you will need to obtain permission directly from the copyright holder. To view a copy of this licence, visit http://creativecommons.org/licenses/by/4.0/.

\section{References}

1. Dural M, Genc E, Sangun MK, Güner Ö (2011) Accumulation of some heavy metals in Hysterothylacium aduncum (Nematoda) and its host sea bream, Sparus aurata (Sparidae) from North-Eastern Mediterranean Sea (Iskenderun Bay). Environ Monit Assess 174: 147-155. https://doi.org/10.1007/s10661-010-1445-0

2. Frémion F, Bordas F, Mourier B, Lenain JF, Kestens T, CourtinNomade A (2016) Influence of dams on sediment continuity: a study case of a natural metallic contamination. Sci Total Environ 547:282-294. https://doi.org/10.1016/j.scitotenv.2016.01.023

3. Gheorghe S, Stoica C, Vasile GG, et al (2017) Metals toxic effects in aquatic ecosystems: modulators of water quality. In: Tutu $\mathrm{H}$ (ed) Water quality. InTech

4. Hasan MR, Khan MZH, Khan M, Aktar S, Rahman M, Hossain F, Hasan ASMM (2016) Heavy metals distribution and contamination in surface water of the Bay of Bengal coast. Cogent Environ Sci 2. https://doi.org/10.1080/23311843.2016.1140001

5. Varol M, Șen B (2012) Assessment of nutrient and heavy metal contamination in surface water and sediments of the upper Tigris River, Turkey. CATENA 92:1-10. https://doi.org/10.1016/j. catena.2011.11.011

6. Y1lmaz AB, Yanar A, Alkan EN (2017) Review of heavy metal accumulation on aquatic environment in Northern East Mediterranean Sea part I: some essential metals. Rev Environ Health 32:119-163. https://doi.org/10.1515/reveh-2016-0065

7. Zuur AF, Ieno EN, Smith GM (2007) Principal component analysis and redundancy analysis. In: Analysing ecological data. Springer New York, New York, NY, pp 193-224

8. Bonnail E, Sarmiento AM, DelValls TA et al (2016) Assessment of metal contamination, bioavailability, toxicity and bioaccumulation in extreme metallic environments (Iberian Pyrite Belt) using Corbicula fluminea. Sci Total Environ 544:1031-1044. https:// doi.org/10.1016/j.scitotenv.2015.11.131

9. Griscom SB, Fisher NS (2004) Bioavailability of sediment-bound metals to marine bivalve molluscs: An overview. Estuaries 27:826838. https://doi.org/10.1007/BF02912044

10. Kwak JI, Cui R, Nam S-H, Kim SW, Chae Y, An YJ (2016) Multispecies toxicity test for silver nanoparticles to derive hazardous concentration based on species sensitivity distribution for the protection of aquatic ecosystems. Nanotoxicology 10:521-530. https://doi.org/10.3109/17435390.2015.1090028

11. Zhou Q, Zhang J, Fu J, Shi J, Jiang G (2008) Biomonitoring: an appealing tool for assessment of metal pollution in the aquatic ecosystem. Anal Chim Acta 606:135-150. https://doi.org/10.1016/j. aca.2007.11.018
12. Cui R, Kwak JI, An Y-J (2018) Comparative study of the sensitivity of Daphnia galeata and Daphnia magna to heavy metals. Ecotoxicol Environ Saf 162:63-70. https://doi.org/10.1016/j. ecoenv.2018.06.054

13. Lari E, Gauthier P, Mohaddes E, Pyle GG (2017) Interactive toxicity of $\mathrm{Ni}, \mathrm{Zn}, \mathrm{Cu}$, and $\mathrm{Cd}$ on Daphnia magna at lethal and sublethal concentrations. J Hazard Mater 334:21-28. https://doi.org/10. 1016/j.jhazmat.2017.03.060

14. Manakul P, Peerakietkhajorn S, Matsuura T, Kato Y, Watanabe H (2017) Effects of symbiotic bacteria on chemical sensitivity of Daphnia magna. Mar Environ Res 128:70-75. https://doi.org/10. 1016/j.marenvres.2017.03.001

15. Bownik A (2017) Daphnia swimming behaviour as a biomarker in toxicity assessment: a review. Sci Total Environ 601-602:194-205. https://doi.org/10.1016/j.scitotenv.2017.05.199

16. Cerveny D, Turek J, Grabic R, Golovko O, Koba O, Fedorova G, Grabicova K, Zlabek V, Randak T (2016) Young-of-the-year fish as a prospective bioindicator for aquatic environmental contamination monitoring. Water Res 103:334-342. https://doi.org/10.1016/j. watres.2016.07.046

17. Habib MR, Mohamed AH, Osman GY, Mossalem HS, Sharaf elDin AT, Croll RP (2016) Biomphalaria alexandrina as a bioindicator of metal toxicity. Chemosphere 157:97-106. https:// doi.org/10.1016/j.chemosphere.2016.05.012

18. Łuczyńska J, Paszczyk B, Łuczyński MJ (2018) Fish as a bioindicator of heavy metals pollution in aquatic ecosystem of Pluszne Lake, Poland, and risk assessment for consumer's health. Ecotoxicol Environ Saf 153:60-67. https://doi.org/10.1016/j. ecoenv.2018.01.057

19. Bhuvaneshwari M, Iswarya V, Vishnu S, Chandrasekaran N, Mukherjee A (2018) Dietary transfer of zinc oxide particles from algae (Scenedesmus obliquus) to daphnia (Ceriodaphnia dubia). Environ Res 164:395-404. https://doi.org/10.1016/j.envres.2018. 03.015

20. Nguyen VT, Satoh S, Haga Y, Fushimi H, Kotani T (2008) Effect of zinc and manganese supplementation in Artemia on growth and vertebral deformity in red sea bream (Pagrus major) larvae. Aquaculture 285:184-192. https://doi.org/10.1016/j.aquaculture. 2008.08.030

21. Skjolding LM, Winther-Nielsen M, Baun A (2014) Trophic transfer of differently functionalized zinc oxide nanoparticles from crustaceans (Daphnia magna) to zebrafish (Danio rerio). Aquat Toxicol 157:101-108. https://doi.org/10.1016/j.aquatox.2014.10.005

22. Zhu X, Wang J, Zhang X, Chang Y, Chen Y (2010) Trophic transfer of $\mathrm{TiO}_{2}$ nanoparticles from daphnia to zebrafish in a simplified freshwater food chain. Chemosphere 79:928-933. https://doi.org/ 10.1016/j.chemosphere.2010.03.022

23. Parmar TK, Rawtani D, Agrawal YK (2016) Bioindicators: the natural indicator of environmental pollution. Front Life Sci 9: 110-118. https://doi.org/10.1080/21553769.2016.1162753

24. Araujo GS, Pavlaki MD, Soares AMVM, Abessa DMS, Loureiro S (2019) Bioaccumulation and morphological traits in a multigeneration test with two Daphnia species exposed to lead. Chemosphere 219:636-644. https://doi.org/10.1016/j. chemosphere.2018.12.049

25. Lu K, Qiao R, An H, Zhang Y (2018) Influence of microplastics on the accumulation and chronic toxic effects of cadmium in zebrafish (Danio rerio). Chemosphere 202:514-520. https://doi.org/10.1016/ j.chemosphere.2018.03.145

26. Zhang J, Hamza I (2018) Zebrafish as a model system to delineate the role of heme and iron metabolism during erythropoiesis. Mol Genet Metab 128:204-212. https://doi.org/10.1016/j.ymgme.2018. 12.007

27. Fernández I, Gavaia PJ, Laizé V, Cancela ML (2018) Fish as a model to assess chemical toxicity in bone. Aquat Toxicol 194: 208-226. https://doi.org/10.1016/j.aquatox.2017.11.015 
28. Harangi S, Baranyai E, Fehér M, Tóth CN, Herman P, Stündl L, Fábián I, Tóthmérész B, Simon E (2017) Accumulation of metals in juvenile carp (Cyprinus carpio) exposed to sublethal levels of iron and manganese: survival, body weight and tissue. Biol Trace Elem Res 177:187-195. https://doi.org/10.1007/s12011-016-0854-5

29. Koivisto S (1995) Is Daphnia magna an ecologically representative zooplankton species in toxicity tests? Environ Pollut 90:263-267. https://doi.org/10.1016/0269-7491(95)00029-Q

30. Qu R-J, Wang X-H, Feng M-B, Li Y, Liu HX, Wang LS, Wang ZY (2013) The toxicity of cadmium to three aquatic organisms (Photobacterium phosphoreum, Daphnia magna and Carassius auratus) under different $\mathrm{pH}$ levels. Ecotoxicol Environ Saf 95:8390. https://doi.org/10.1016/j.ecoenv.2013.05.020

31. Tan C, Wang W-X (2014) Modification of metal bioaccumulation and toxicity in Daphnia magna by titanium dioxide nanoparticles. Environ Pollut 186:36-42. https://doi.org/10.1016/j.envpol.2013. 11.015

32. Cardwell RD, DeForest DK, Brix KV, Adams WJ (2013) Do cd, $\mathrm{cu}, \mathrm{Ni}, \mathrm{Pb}$, and $\mathrm{Zn}$ biomagnify in aquatic ecosystems? In: Whitacre DM (ed) Reviews of environmental contamination and toxicology, vol 226. Springer New York, New York, NY, pp 101-122

33. Rubio-Franchini I, López-Hernández M, Ramos-Espinosa MG, Rico-Martínez R (2016) Bioaccumulation of metals arsenic, cadmium, and lead in zooplankton and fishes from the Tula River Watershed, Mexico. Water Air Soil Pollut 227:5. https://doi.org/ 10.1007/s11270-015-2702-1

34. Oberholster PJ, Myburgh JG, Ashton PJ, Coetzee JJ, Botha AM (2012) Bioaccumulation of aluminium and iron in the food chain of Lake Loskop, South Africa. Ecotoxicol Environ Saf 75:134-141. https://doi.org/10.1016/j.ecoenv.2011.08.018

35. Chandra Sekhar K, Chary NS, Kamala CT, Suman Raj DS, Sreenivasa Rao A (2004) Fractionation studies and bioaccumulation of sediment-bound heavy metals in Kolleru lake by edible fish. Environ Int 29:1001-1008. https://doi.org/10.1016/S01604120(03)00094-1

36. Rajeshkumar S, Li X (2018) Bioaccumulation of heavy metals in fish species from the Meiliang Bay, Taihu Lake, China. Toxicol Rep 5:288-295. https://doi.org/10.1016/j.toxrep.2018.01.007

37. Jitar O, Teodosiu C, Oros A, Plavan G, Nicoara M (2015) Bioaccumulation of heavy metals in marine organisms from the Romanian sector of the Black Sea. New Biotechnol 32:369-378. https://doi.org/10.1016/j.nbt.2014.11.004

38. Mathews T, Fisher N (2008) Trophic transfer of seven trace metals in a four-step marine food chain. Mar Ecol-Prog Ser - MAR ECOLPROGR SER 367:23-33. https://doi.org/10.3354/meps07536

39. Hwang D-W, Kim S-S, Kim S-G, Kim DS, Kim TH (2017) Erratum to: Concentrations of heavy metals in marine wild fishes captured from the Southern Sea of Korea and associated health risk assessments. Ocean Sci J 52:467-467. https://doi.org/10.1007/ s12601-017-0048-x

40. Bosch AC, O'Neill B, Sigge GO et al (2016) Heavy metals in marine fish meat and consumer health: a review: heavy metals in marine fish meat. J Sci Food Agric 96:32-48. https://doi.org/10. $1002 /$ jsfa. 7360

41. Feng X, Meng B, Yan H, Fu X, Yao H, Shang L, Feng X, Meng B, Yan H, Fu X, Yao H, Shang L (2018) Bioaccumulation of mercury in aquatic food chains. In: Biogeochemical cycle of mercury in reservoir systems in Wujiang River Basin. Southwest China. Springer Singapore, Singapore, pp 339-389

42. Lavoie RA, Jardine TD, Chumchal MM, Kidd KA, Campbell LM (2013) Biomagnification of mercury in aquatic food webs: a worldwide meta-analysis. Environ Sci Technol 47:13385-13394. https:// doi.org/10.1021/es403103t

43. Espejo W, Padilha J de A, Kidd KA, et al (2018) Trophic transfer of cadmium in marine food webs from Western Chilean Patagonia and
Antarctica. Mar Pollut Bull 137:246-251. https://doi.org/10.1016/j. marpolbul.2018.10.022

44. Leszczyńska K (1997) The accumulation of $\mathrm{Cd}, \mathrm{Pb}$ and $\mathrm{Cu}$ in the aquatic food chains in three lakes differing in the trophic conditions. SIL Proc 1922-2010 26:517-519. https://doi.org/10.1080/ 03680770.1995 .11900769

45. World Health Organization (ed) (2011) Guidelines for drinkingwater quality, 4th edn. World Health Organization, Geneva

46. Ekström SM, Regnell O, Reader HE, Nilsson PA, Löfgren S, Kritzberg ES (2016) Increasing concentrations of iron in surface waters as a consequence of reducing conditions in the catchment area. J Geophys Res Biogeosci 121:479-493. https://doi.org/10. 1002/2015jg003141

47. Balcu I, Amalia C, Segneanu A-E, Oana R (2011) Combined microwave-acid pretreatment of the biomass. In: Shaukat S (ed) Progress in biomass and bioenergy production. InTech

48. Balogh Z, Harangi S, Kundrát JT, Gyulai I, Tóthmérész B, Simon E (2016) Effects of anthropogenic activities on the elemental concentration in surface sediment of oxbows. Water Air Soil Pollut 227. https://doi.org/10.1007/s11270-015-2714-x

49. Balogh Z, Harangi S, Gyulai I, Braun M, Hubay K, Tóthmérész B, Simon E (2017) Exploring river pollution based on sediment analysis in the Upper Tisza region (Hungary). Environ Sci Pollut Res 24:4851-4859. https://doi.org/10.1007/s11356-016-8225-5

50. Ódor L, Horváth I, Fügedi U (1997) Low-density geochemical mapping in Hungary. J Geochem Explor 60:55-66. https://doi. org/10.1016/S0375-6742(97)00025-3

51. AVMA Guidelines for the Euthanasia of Animals (2013) Edition. https://norecopa.no/textbase/avma-guidelines-for-the-euthanasiaof-animals-2013-edition. Accessed 23 Apr 2019

52. Fehér M, Baranyai E, Simon E, Bársony P, Szücs I, Posta J, Stündl L (2013) The interactive effect of cobalt enrichment in Artemia on the survival and larval growth of barramundi, Lates calcarifer. Aquaculture 414-415:92-99. https://doi.org/10.1016/j. aquaculture.2013.07.031

53. Handbook of property estimation methods for chemicals: environmental health sciences. In: CRC Press. https://www.crcpress.com/ Handbook-of-Property-Estimation-Methods-for-ChemicalsEnvironmental-Health/Mackay-Boethling/p/book/ 9781566704564. Accessed 23 Apr 2019

54. (2007) Principal component analysis and redundancy analysis. In: Analysing ecological data. Springer New York, New York, NY, pp 193-224

55. Tuzuki BLL, Delunardo FAC, Ribeiro LN et al (2017) Effects of manganese on fat snook Centropomus parallelus (Carangaria: Centropomidae) exposed to different temperatures. Neotropical Ichthyol 15. https://doi.org/10.1590/1982-0224-20170054

56. Peters A, Lofts S, Merrington G, Brown B, Stubblefield W, Harlow K (2011) Development of biotic ligand models for chronic manganese toxicity to fish, invertebrates, and algae. Environ Toxicol Chem 30:2407-2415. https://doi.org/10.1002/etc.643

57. Dolci GS, Dias VT, Roversi K, Roversi K, Pase CS, Segat HJ, Teixeira AM, Benvegnú DM, Trevizol F, Barcelos RCS, Riffel APK, Nunes MAG, Dressler VL, Flores EMM, Baldisserotto B, Bürger ME (2013) Moderate hypoxia is able to minimize the manganese-induced toxicity in tissues of silver catfish (Rhamdia quelen). Ecotoxicol Environ Saf 91:103-109. https://doi.org/10. 1016/j.ecoenv.2013.01.013

58. Gabriel D, Riffel APK, Finamor IA, Saccol EMH, Ourique GM, Goulart LO, Kochhann D, Cunha MA, Garcia LO, Pavanato MA, Val AL, Baldisserotto B, Llesuy SF (2013) Effects of subchronic manganese chloride exposure on Tambaqui (Colossoma macropomum) tissues: oxidative stress and antioxidant defenses. Arch Environ Contam Toxicol 64:659-667. https://doi.org/10. 1007/s00244-012-9854-4 
59. Adolfsson-Erici M, Åkerman G, McLachlan MS (2012) Measuring bioconcentration factors in fish using exposure to multiple chemicals and internal benchmarking to correct for growth dilution. Environ Toxicol Chem 31:1853-1860. https://doi.org/10.1002/etc. 1897

60. Vieira MC, Torronteras R, Córdoba F, Canalejo A (2012) Acute toxicity of manganese in goldfish Carassius auratus is associated with oxidative stress and organ specific antioxidant responses. Ecotoxicol Environ Saf 78:212-217. https://doi.org/10.1016/j. ecoenv.2011.11.015

61. Marins K, Lazzarotto LMV, Boschetti G, Bertoncello KT, Sachett A, Schindler MSZ, Chitolina R, Regginato A, Zanatta AP, Siebel AM, Magro JD, Zanatta L (2019) Iron and manganese present in underground water promote biochemical, genotoxic, and behavioral alterations in zebrafish (Danio rerio). Environ Sci Pollut Res 26: 23555-23570. https://doi.org/10.1007/s11356-019-05621-0

62. Tu H, Fan C, Chen X, Liu J, Wang B, Huang Z, Zhang Y, Meng X, Zou F (2017) Effects of cadmium, manganese, and lead on locomotor activity and neurexin $2 \mathrm{a}$ expression in zebrafish: effects of metals on neurexin 2a expression in zebrafish. Environ Toxicol Chem 36:2147-2154. https://doi.org/10.1002/etc.3748

63. Altenhofen S, Wiprich MT, Nery LR, Leite CE, Vianna MRMR, Bonan CD (2017) Manganese (II) chloride alters behavioral and neurochemical parameters in larvae and adult zebrafish. Aquat Toxicol 182:172-183. https://doi.org/10.1016/j.aquatox.2016.11. 013

64. Voigt CL, da Silva CP, Doria HB, Randi MAF, de Oliveira Ribeiro CA, de Campos SX (2015) Bioconcentration and bioaccumulation of metal in freshwater Neotropical fish Geophagus brasiliensis. Environ Sci Pollut Res 22:8242-8252. https://doi.org/10.1007/ s11356-014-3967-4

65. Vuori K-M (1995) Direct and indirect effects of iron on river ecosystems. Ann Zool Fenn 32:317-329

66. Wu P, Kainz MJ, Bravo AG, Åkerblom S, Sonesten L, Bishop K (2019) The importance of bioconcentration into the pelagic food web base for methylmercury biomagnification: a meta-analysis. Sci
Total Environ 646:357-367. https://doi.org/10.1016/j.scitotenv. 2018.07.328

67. Mathews T, Fisher NS (2008) Evaluating the trophic transfer of cadmium, polonium, and methylmercury in an estuarine food chain. Environ Toxicol Chem 27:1093-1101. https://doi.org/10.1897/07318.1

68. Dallinger R, Prosi F, Segner H, Back H (1987) Contaminated food and uptake of heavy metals by fish: a review and a proposal for further research. Oecologia 73:91-98. https://doi.org/10.1007/ BF00376982

69. Oweson C, Hernroth B (2009) A comparative study on the influence of manganese on the bactericidal response of marine invertebrates. Fish Shellfish Immunol 27:500-507. https://doi.org/10. 1016/j.fsi.2009.07.001

70. Kawasaki LY, Tarifeño-Silva E, Yu DP, Gordon MS, Chapman DJ (1982) Aquacultural approaches to recycling of dissolved nutrients in secondarily treated domestic wastewaters - I Nutrient uptake and release by artificial food chains. Water Res 16:37-49. https://doi. org/10.1016/0043-1354(82)90051-3

71. Wang W (2002) Interactions of trace metals and different marine food chains. Mar Ecol Prog Ser 243:295-309. https://doi.org/10. 3354/meps243295

72. Croteau M-N, Luoma SN, Stewart AR (2005) Trophic transfer of metals along freshwater food webs: evidence of cadmium biomagnification in nature. Limnol Oceanogr 50:1511-1519. https://doi.org/10.4319/lo.2005.50.5.1511

73. Wg W, Gr L (1997) Bioavailability of biologically sequestered cadmium and the implications of metal detoxification. Mar Ecol Prog Ser 147:149-157. https://doi.org/10.3354/meps147149

74. Arnot JA, Gobas FA (2006) A review of bioconcentration factor (BCF) and bioaccumulation factor (BAF) assessments for organic chemicals in aquatic organisms. Environ Rev 14:257-297. https:// doi.org/10.1139/a06-005

Publisher's Note Springer Nature remains neutral with regard to jurisdictional claims in published maps and institutional affiliations. 